\title{
Synthetic diets for young pigs
}

\author{
BY R. BLAIR* \\ Rowett Research Institute, Bucksburn, Aberdeen
}

(Received 6 October 1961-Revised 5 October 1962)

This report is the first of a series describing experiments with the overall aim of determining the requirements of the young pig for calcium and phosphorus.

Because so little is known about the availability of the minerals present in different feeding-stuffs it seemed best to use synthetic diets with known sources of $\mathrm{Ca}$ and $\mathrm{P}$ in these investigations.

The synthetic diets used in all the experiments conducted so far on very young pigs have been liquids resembling sow's or cow's milk (cf. Wintrobe, 1939; Johnson, James \& Krider, I948; Wiese, Lehrer, Moore, Pahnish \& Hartwell, I95I; Catron, Nelson, Ashton \& Maddock, I953; Miller, Schmidt, Ullrey, Hoefer \& Luecke, 1957). These artificial milks, though for the most part giving excellent results, are laborious to prepare and in practice entail more work than dry diets since the feed containers need frequent and thorough cleaning. Dry diets can be mixed and stored in quantity and are simple to handle.

I attempted, therefore, to prepare synthetic diets that could be given as air-dry mixtures to pigs from ro days of age until they attained $25 \mathrm{lb}$ live weight, and from 25 to $50 \mathrm{lb}$ live weight. Since nutritional requirements alter as pigs grow older (Lucas \& Lodge, 196r), separate basal diets were prepared for each of these stages. Two basal diets, one containing lard and the other coconut oil, were prepared for pigs weighing $8-25 \mathrm{lb}$ and in a first preliminary experiment each diet was modified by the addition of saccharin (Notzold, Becker, Terrill \& Jensen, 1955; Aldinger, Homeyer, Speer, Hays \& Catron, 1957) to test whether acceptability was low and could be improved by including a sweetening agent, and by the addition of cellulose to test whether an indigestible component was necessary. In a second preliminary experiment the lard diet was modified by the addition of DL-methionine, because casein on the basis of its amino acid composition did not appear to be the ideal protein for young pigs, and by varying the level of vitamin and trace-mineral supplements because requirements for these nutrients were by no means certain (Lucas \& Lodge, r $96 \mathrm{I}$ ). In both preliminary experiments two basal diets, differing in their relative content of sugars and starch, were used for the pigs weighing $25-50 \mathrm{lb}$. Although these preliminary experiments involved only a small number of pigs they did not indicate that any of the modifications tested improved the basal diets, apart from the suggestion that a higher level of vitamins and trace minerals was beneficial. Because of the possible beneficial effect of increased vitamins and minerals a larger experiment involving forty-eight young pigs was carried out in which the vitamin and trace-mineral supplements in the lard

* Present address: Department of Agriculture, University of Aberdeen. 
diet were tested separately at two levels to find which supplement caused the improvement, and the same two basal diets as used previously for the pigs weighing $25-50 \mathrm{lb}$ were retested.

In the past no synthetic diets appear to have been given as air-dry mixtures to Io-day-old pigs although they have been used with success for 3-week-old pigs (Powick, Ellis, Madsen \& Dale, 1947; Peo, Hays, Ashton, Speer, Liu \& Catron, 1957).

Table I. Percentage composition of the basal diets

\begin{tabular}{|c|c|c|c|}
\hline & Diet I & Diet $\mathbf{I}_{3}$ & Diet 14 \\
\hline & $\begin{array}{l}\text { Given before } \\
25 \text { lb live weight }\end{array}$ & $\begin{array}{r}\mathrm{G} \\
25 \mathrm{lb}\end{array}$ & eight \\
\hline Casein ${ }^{1}$ & 30 & 20 & 20 \\
\hline Maize starch & 15 & $46 \cdot 3$ & 20 \\
\hline Glucose & $31 \cdot 3$ & 10 & 23 \\
\hline Sucrose & 10 & 10 & $23 \cdot 3$ \\
\hline Lard & 5 & $2 \cdot 5$ & $2 \cdot 5$ \\
\hline Maize oil & $\circ$ & $2 \cdot 5$ & $2 \cdot 5$ \\
\hline Vitamin supplement ${ }^{2}$ & I & I & $\mathbf{I}$ \\
\hline Trace-mineral supplement ${ }^{3}$ & I & I & $\mathbf{I}$ \\
\hline Calcium and phosphorus supplement ${ }^{4}$ & 5 & 5 & 5 \\
\hline Potassium supplement ${ }^{6}$ & I & $\mathbf{I}$ & I \\
\hline Sodium chloride & 0.5 & 0.5 & 0.5 \\
\hline Chlortetracycline hydrochloride ${ }^{\mathrm{g}}$ & + & + & + \\
\hline Nystatin 7 & + & + & + \\
\hline
\end{tabular}

1 Casein C (lactic casein-unextracted; Glaxo Laboratories Ltd).

2 Contained (per $\mathrm{kg}$ ): thiamine hydrochloride $264 \mathrm{mg}$, riboflavin $330 \mathrm{mg}$, nicotinic acid $2970 \mathrm{mg}$, calcium pantothenate $1914 \mathrm{mg}$, pyridoxine hydrochloride $132 \mathrm{mg}$, cyanocobalamin $2.6 \mathrm{mg}$, folic acid $5.5 \mathrm{mg}$, biotin $\mathrm{I} \cdot \mathrm{I} \mathrm{mg}$, choline chloride $26000 \mathrm{mg}$, inositol $2600 \mathrm{mg}$, p-aminobenzoic acid $260 \mathrm{mg}$, vitamin $A_{125400}$ i.u., vitamin $D_{3} 33000$ i.u., $\alpha$-tocopheryl acetate $99 \mathrm{mg}$, maize starch $965 \mathrm{~g}$.

${ }^{3}$ Contained (per kg): $\mathrm{FeSO}_{4} \cdot 7 \mathrm{H}_{2} \mathrm{O} 99 \cdot 6 \mathrm{~g}, \mathrm{MgSO}_{4} \cdot 7 \mathrm{H}_{2} \mathrm{O}_{302} \cdot 3 \mathrm{~g}, \mathrm{CuSO}_{4} \cdot \mathrm{H}_{2} \mathrm{O}_{7} \cdot 6 \mathrm{~g}, \mathrm{MnSO}_{4} \cdot 4 \mathrm{H}_{2} \mathrm{O}$ $16.3 \mathrm{~g}, \mathrm{ZnSO}_{4} \cdot 7 \mathrm{H}_{2} \mathrm{O} 43.3 \mathrm{~g}, \mathrm{KIO}_{3} \mathrm{O} .17 \mathrm{~g}, \mathrm{CoSO}_{4} .7 \mathrm{H}_{2} \mathrm{O} 0.94 \mathrm{~g}$, maize starch $530 \mathrm{~g}$.

- Contained (per kg): $\mathrm{CaHPO}_{3} 595 \mathrm{~g}$, sucrose $405 \mathrm{~g}$ in diet $\mathrm{I}$, and $\mathrm{CaHPO}_{4} 40 \mathrm{~g}$, sucrose $560 \mathrm{~g}$ in diets 13 and 14.

5 Contained (per $\mathrm{kg}$ ): $\mathrm{K}_{2} \mathrm{SO}_{4} 720 \mathrm{~g}$, sucrose $280 \mathrm{~g}$.

- Aureomycin hydrochloride $98 \%$ (Lederle Laboratories Inc.) $2 \mathrm{~g} / \mathrm{r} 00 \mathrm{lb}$.

? Mycostatin 20 (containing $20 \mathrm{~g}$ nystatin/lb; E. R. Squibb and Sons Ltd) $102 \mathrm{~g} / \mathrm{l} 00 \mathrm{lb}$ (see p. 6).

\section{EXPERIMENTAL}

\section{Preliminary experiments}

Diets. The composition of the basal diets used in these experiments is shown in Table $\mathrm{r}$. Nystatin, however, was not added at this stage (see p. 6). The diets were made up to provide adequate amounts of those nutrients for which a requirement has been established (Lodge \& Lucas, 1959; Lucas \& Lodge, 1961). For the vitamins of the $B$ complex, of which the requirement is unknown, quantities shown to be adequate for the young calf (Wiese, Johnson, Mitchell \& Nevens, 1947) were taken as a guide. $\mathrm{Ca}$ and $\mathrm{P}$ were added to the diet as calcium hydrogen orthophosphate $\left(\mathrm{CaHPO}_{4}\right)$ in which the ratio $\mathrm{Ca}: \mathrm{P}$ is about $\mathrm{I}_{3} \cdot \mathrm{I}$ I by weight, close to that recommended by Freese (1958) for sow's-milk substitutes. The Ca level was based on the estimated requirement of the 20-45 lb pig (Lodge \& Lucas, 1959).

Sodium chloride was included at the rate of $0.5 \%$, this being the amount normally added to early-weaning diets which already contain some $\mathrm{Na}$ and $\mathrm{Cl}$. The amount of 
$\mathrm{K}$ added was based on the $\mathrm{K}$ requirement of the $25-4 \mathrm{O} \mathrm{lb}$ pig (Lodge \& Lucas, 1959). The trace-mineral mixture was based on that of Lucas, Calder \& Smith (1959) modified to meet the estimate of dietary requirements drawn up by Lodge \& Lucas (1959).

Chlortetracycline hydrochloride was included since Calder, Lodge \& Blair (1959) found that growth was better and the incidence of disease was lower on a diet containing antibiotic.

It was considered that some fat should be added as a source of fatty acids and to improve the texture of the diet. There was doubt, however, about the best fat to use, so lard was compared with coconut oil, the former since it is the body fat of the pig, and the latter since it contains a larger proportion of the lower fatty acids which, according to Lloyd \& Crampton (1957), are utilized better by the young pig than the higher fatty acids. Part of the fat added to the diets for pigs of $25-40 \mathrm{lb}$ live weight was maize oil which allowed these diets, eaten in greater amount, to be mixed more easily.

The basal starter diet, no. I for pigs of from 8 to 25 lb live weight (Table 1 ), was modified in the ways shown to give the diets listed below.

\begin{aligned} Diet no. & \multicolumn{1}{c}{ Preliminary Expt I } \\ I & Basal diet no. I (Table I) but without nystatin \\ 2 & Basal diet no. I with lard replaced by coconut oil \\ 3 & Saccharin $(0.05 \%)$ added to no. I \\ 4 & Saccharin $(0.05 \%)$ added to no. 2 \\ 5 & Cellulose $(2 \%)$ added to no. I \\ 6 & Cellulose $(2 \%)$ added to no. 2 \\ 7 & Cellulose $(2 \%)$ added to no. 3 \\ 8 & Cellulose $(2 \%)$ added to no. 4 \\ & $\quad$ Preliminary Expt 2 \\ 9 & Basal diet no. I but without nystatin \\ I0 & No. I with vitamin and trace-mineral supplements raised to $2 \% \\$ I I & DL-methionine $(50 \mathrm{~g} / \mathrm{ro0} \mathrm{lb})$ added to no. I \\ I 2 & DL-methionine $(50 \mathrm{~g} / 100 \mathrm{lb})$ added to no. 2\end{aligned}

On reaching $25 \mathrm{lb}$ live weight all the pigs from the first preliminary experiment and half of those from the second were fed on diet 13 , while the remainder were fed on diet $I_{4}$ (Table $\mathrm{I}$ ). Diets $\mathrm{I}_{3}$ and $\mathrm{I}_{4}$ contained different proportions of sugars and starch since, although the $25 \mathrm{lb}$ pig is well able to utilize starch (Lucas \& Lodge, 196r), a diet containing most of its carbohydrate in this cheaper form might be unacceptable.

Procedure. At 14 days of age the pigs were weaned and ear-marked and the males castrated. From weaning to $25 \mathrm{lb}$ live weight the animals were individually housed and fed in cages (Smith \& Lucas, $195^{6-7}$ ), and from $25 \mathrm{lb}$ to 56 days of age they were in small wooden huts with outside runs on concrete (Smith \& Lucas, 1957). During both periods the pigs were fed $a d l i b$., and were provided with drinking water in separate troughs.

The animals were weighed at the beginning of the experiment and subsequently

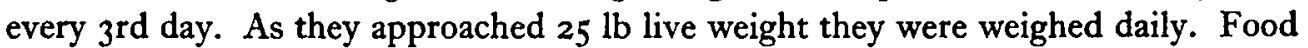
was weighed as required and unconsumed food was weighed every $3^{\text {rd day }}$ to give the amount eaten in each 3-day period. A record of the incidence of scouring up to $25 \mathrm{lb}$ live weight was also made. 
No pig was dosed with iron since they had all been reared to ro days of age in huts with access to grass and the synthetic diets contained sufficient iron to prevent anaemia.

In the first preliminary experiment eight litter-mate Wessex Saddleback pigs were used to test diets $I-8$, one pig being allocated to each of the eight diets. As the experiment was of a $2 \times 2 \times 2$ factorial design, four pigs received the diets based on lard and four those based on coconut oil, four received the diets with saccharin and four those without saccharin, four received the diets with cellulose and four those without cellulose. In the second preliminary experiment eight litter-mate Wessex Saddleback pigs were used to test diets 9-12, two pigs being allocated to each diet. As the experiment was of a $2 \times 2$ factorial design four pigs received the diets containing $1 \%$ of vitamin and trace-mineral supplements and four those containing $2 \%$ of vitamin and trace-mineral supplements, four received the diets with DL-methionine and four those without DL-methionine.

\section{Main experiment}

Plan. As a result of the findings in the preliminary experiments, the main experiment was designed to test the effect of including 1 or $2 \%$ vitamin supplement and I or $2 \%$ trace-mineral supplement in the diet given from 8 to $25 \mathrm{lb}$ live weight, followed by the high-starch or low-starch diet ( 13 or 14 in Table $\mathrm{I}$ ) from 25 to $50 \mathrm{lb}$ live weight. Thus the eight treatments were:

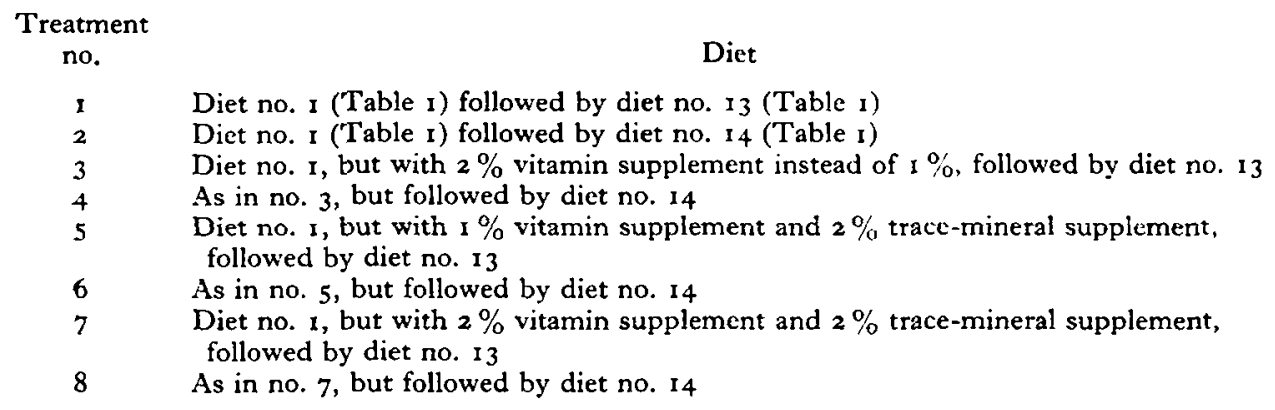

Six litters of eight pigs were used to test the eight treatments and each litter represented a complete replicate of the experiment, which was of a $2 \times 2 \times 2$ factorial design. Twenty-four pigs received diet no. I with I $\%$ vitamin supplement and twenty-four received diet no. I with $2 \%$ vitamin supplement, twenty-four received diet no. I with I $\%$ trace-mineral supplement and twenty-four received diet no. I with $2 \%$ trace-mineral supplement, twenty-four received diet no. 13 , and twenty-four received diet no. I4.

Animals. Of the six litters used, two were Wessex Saddleback, three were Large White $\times$ Wessex Saddleback and one was Landrace $\times$ Wessex Saddleback. The pigs were taken from the sows at ro days of age, weighed, ear-numbered and the males castrated. Allocation to the experimental treatment according to a randomized plan was then made, sex being disregarded.

The management of the animals was similar to that in the preliminary experiments. 
Statistical methods. The results were analysed by the conventional analysis of variance technique. Missing values were fitted by the usual methods and in consequence the standard errors given are approximate.

\section{RESULTS}

\section{Preliminary experiments}

The performance of the pigs on all the treatments in both preliminary experiments is shown in Table 2.

The mean rate of weight gain after the first few days was rapid and the final weights at 8 weeks were high compared with a figure of $38.5 \mathrm{lb}$ found previously for suckled animals at this Institute (Lodge \& McDonald, 1959).

Table 2. Performance of pigs with various diets in two preliminary experiments

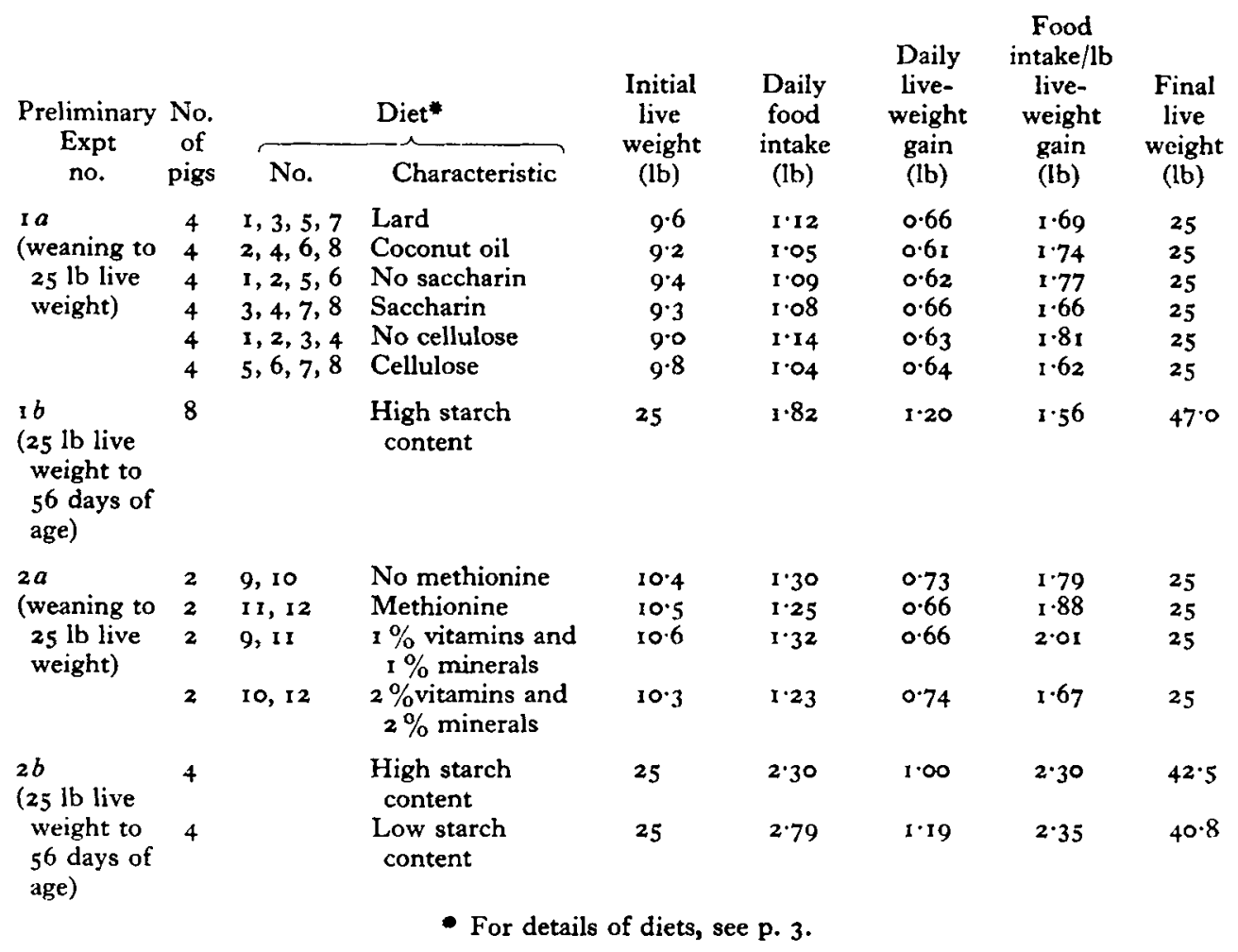

There was no evidence of any advantage in substituting coconut oil for lard, or of including saccharin, cellulose or DL-methionine in the diet given during the period from weaning to $25 \mathrm{lb}$ live weight. However, the pigs grew $12 \%$ faster and converted the feed $17 \%$ more efficiently on the diets containing $2 \%$ of vitamin and tracemineral supplements than they did on the diets containing only I \%. Both diets given after a live weight of $25 \mathrm{lb}$ had been attained gave excellent results. 
Health

\section{Main experiment}

Two pigs had to be discarded before they attained $25 \mathrm{lb}$ live weight owing to generalized coliform infection, and later one pig died from moniliasis. Scouring was encountered in all the litters and was not significantly more prevalent on one treatment than on any of the others. The severity of scouring was reduced by starving the pigs for $12-24 \mathrm{~h}$ without reducing water intake and then adding to the drinking-water either 3-nitro-4-hydroxyphenyl arsonic acid or a mixture of nitrofurazones and furazolidone. The overall mean incidence was 2 days' scouring per pig in period $\mathrm{I}$, during which the live weight increased from 8 to $25 \mathrm{lb}$.

After moniliasis had been diagnosed as the cause of death of the animal referred to above, other pigs were found to show signs of the disease, namely reddening of the skin and a general appearance of unthriftiness together with a poor appetite and reduced rate of weight gain. Therefore nystatin, an antibiotic which has been shown to be effective against Candida albicans, the causal agent of moniliasis (Yacowitz, Wind, Jambor, Semar \& Pagano, I957; Combs, Romoser \& Shaffner, I958), was incorporated in the diet at the rate of $100 \mathrm{~g} /$ ton. No further trouble was encountered.

\section{Leg deformities}

At $50 \mathrm{lb}$ live weight the animals were examined for leg deformities, when thirtythree of the forty-five pigs, distributed uniformly over all the litters and treatments, showed obvious bowing or in-turning of the fore or hind limbs (PI. I). After reaching $50 \mathrm{lb}$ and while being fed on a commercial diet for growing pigs one pig became subject to sudden attacks of convulsions and died. Post-mortem examination showed that death was due to a generalized infection. The bones of one of the forelegs were removed and compared radiologically with the bones of a sow-reared pig of similar age and live weight. It was found that calcification of the bones was poor. Consequently after the end of the experiment attempts were made to improve the leg condition of the remaining pigs in that litter. $\mathrm{Mg}$ or $\mathrm{Mn}$, which are known to affect bone growth, were added in greater amount to the diet. Although pigs do not appear to have a dietary requirement for vitamin $\mathrm{C}$, the bone deformities resembled those associated with scurvy (Follis, $195^{8}$ ) and therefore injections of vitamin $\mathrm{C}$ were given to some of the pigs. Crude liver extract was given to others. None of these treatments resulted in an obvious improvement in the condition although a gradual improvement did take place on a commercial diet for growing pigs.

\section{Period I (from 8 to 25 lb live weight)}

Performance. The dietary treatments had no effect on food consumption, liveweight gain, food-conversion efficiency or incidence of scouring (Table 3).

Fig. I shows the mean weight curves of the animals in this experiment and in an experiment conducted by Smith \& Lucas (1957). The weight increase of all the animals in both experiments followed a similar trend but on average the check after weaning was more prolonged in the animals fed on synthetic diets, probably because 
weight at weaning was lower. After this check, however, the animals fed on synthetic diets grew faster than those in the experiment described by Smith \& Lucas (1957), so that both groups reached $25 \mathrm{lb}$ at the same age.

Table 3. Main experiment. Mean performance of the pigs from 8 to 25 lb live weight

\begin{tabular}{|c|c|c|c|c|c|c|c|c|}
\hline$\frac{\text { Dietary }}{\begin{array}{c}\text { Vitamins } \\
(\%)\end{array}}$ & $\underbrace{\text { reatment }}_{\substack{\text { Minerals } \\
(\%)}}$ & $\begin{array}{l}\text { No. } \\
\text { of } \\
\text { pigs }\end{array}$ & $\begin{array}{l}\text { Initial } \\
\text { live } \\
\text { weight } \\
\text { (lb) }\end{array}$ & $\begin{array}{l}\text { Daily } \\
\text { food } \\
\text { intake } \\
\text { (lb) }\end{array}$ & $\begin{array}{l}\text { Daily } \\
\text { live-weight } \\
\text { gain } \\
\text { (lb) }\end{array}$ & $\begin{array}{c}\text { Food } \\
\text { intake/lb } \\
\text { live-weight } \\
\text { gain } \\
\text { (lb) }\end{array}$ & $\begin{array}{l}\text { Incidence } \\
\text { of } \\
\text { scouring } \\
\text { (days) }\end{array}$ & $\begin{array}{l}\text { Final } \\
\text { live } \\
\text { weight } \\
\text { (lb) }\end{array}$ \\
\hline I & $\mathbf{I}$ & 12 & 8.0 & $1 \cdot 12$ & 0.63 & $I \cdot 83$ & $2 \cdot 4$ & 25 \\
\hline I & 2 & 12 & $7 \cdot 9$ & I $\cdot$ I I & 0.64 & $I \cdot 76$ & $I \cdot 7$ & 25 \\
\hline 2 & $\mathbf{I}$ & 12 & $7 \cdot 9$ & $I \cdot 10$ & 0.63 & $I \cdot 74$ & $2 \cdot 0$ & 25 \\
\hline 2 & 2 & 12 & $8 \cdot 0$ & $I \cdot 13$ & 0.65 & $1 \cdot 73$ & $2 \cdot 3$ & 25 \\
\hline \multicolumn{4}{|c|}{ S.E. of means } & \pm 0.02 & \pm 0.02 & \pm 0.06 & \pm 0.5 & \\
\hline
\end{tabular}

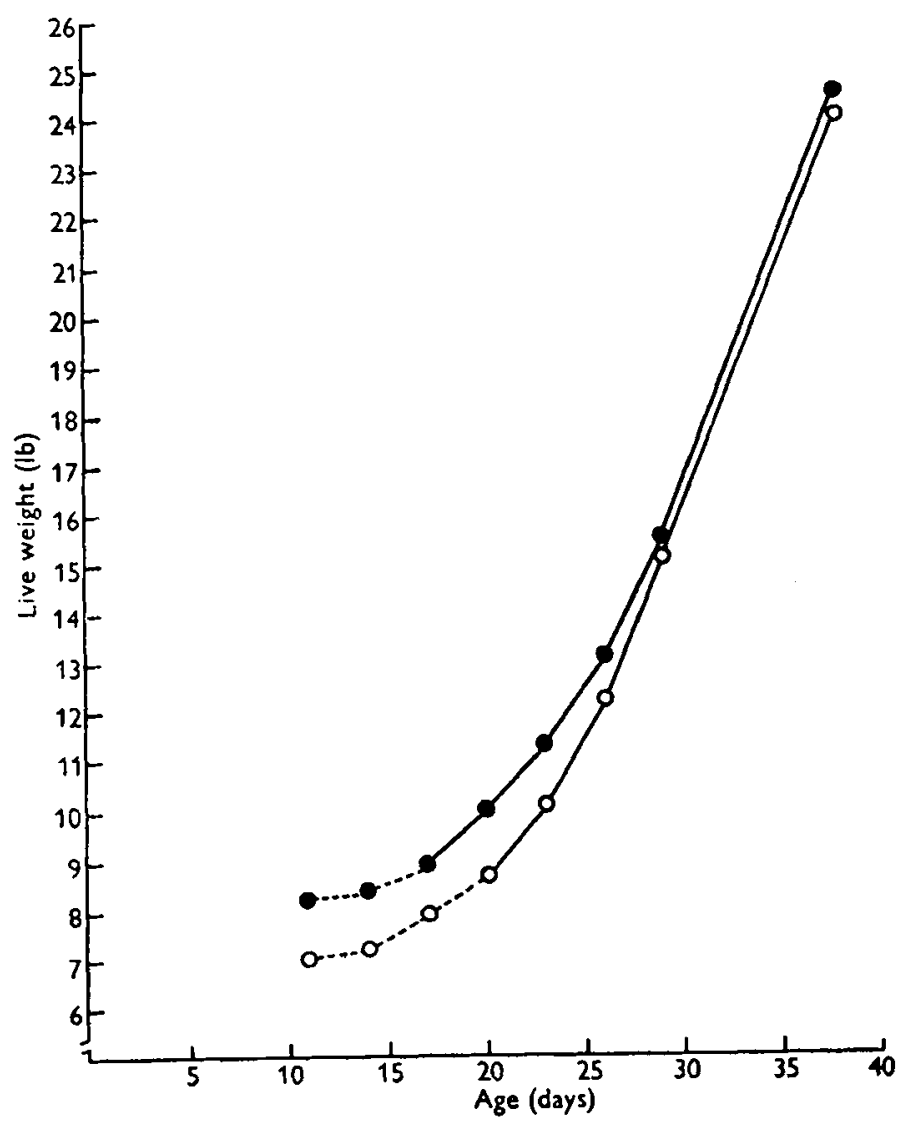

Fig. I. Growth curves of pigs weaned at about to days of age and given dry-meal diets. $O-O$, pigs given synthetic diets (this work); - pigs given non-synthetic diets (Smith \& Lucas, 1957); - - , check period; —_, growing period. 
Period 2 (from 25 to 50 lb live weight)

Performance. The performance of the animals between 25 and $50 \mathrm{lb}$ is shown in Table 4.

Table 4. Main experiment. Mean performance of the pigs from 25 to $50 \mathrm{lb}$ live weight (six pigs in each of eight groups)

Dietary treatment during period 2
Dietary treatment during period I

$\begin{array}{llll}\text { I } \% \text { vitamins } & \text { I } \% \text { vitamins } & 2 \% \text { vitamins } & 2 \% \text { vitamins } \\ \text { I } \% \text { minerals } & 2 \% \text { minerals } & \text { I } \% \text { minerals } & 2 \% \text { minerals }\end{array}$

Period 2 treatment means

(a) Mean daily food consumption (lb)

High-starch
Low-starch
Period I treatment
means

(b) Mean amount of food consumed (lb)/lb live-weight gain

$\begin{array}{ll}\text { High-starch } & \text { I } 75 \\ \text { Low-starch } & \text { I } 75 \\ \text { Period I treatment } & \text { I } 75 \\ \text { means } & \\ & \\ & \\ \text { High-starch } & \mathrm{I} \cdot \mathbf{1 6} \\ \text { Low-starch } & \mathrm{I} \cdot \mathbf{2 8} \\ \text { Period I treatment } & \mathbf{1} \cdot \mathbf{2 2} \\ \text { means } & \end{array}$
means

$\begin{array}{llll}I \cdot 75 & I \cdot 83 & I \cdot 84 & I \cdot 77 \\ 1 \cdot 75 & 2 \cdot 28 & I \cdot 81 & 1 \cdot 94 \\ I \cdot 75 & 2.05 & I \cdot 82 & I \cdot 85\end{array}$

\section{(c) Mean daily live-wcight gain (lb)}

$\begin{array}{lllll}2 \cdot 02 & 2 \cdot 16 & 2 \cdot 19 & 2 \cdot 28 & 2 \cdot 16 \\ 2 \cdot 23 & 2 \cdot 48 & 2 \cdot 44 & 2 \cdot 51 & 2 \cdot 42 \\ 2 \cdot 12 & 2 \cdot 32 & 2 \cdot 32 & 2 \cdot 40 & \end{array}$

$\begin{array}{lllll}I \cdot 16 & I \cdot 18 & I \cdot 20 & I \cdot 29 & I \cdot 21 \\ I \cdot 28 & I \cdot 13 & I \cdot 38 & I \cdot 32 & I \cdot 28 \\ I \cdot 22 & I \cdot 16 & I \cdot 29 & I \cdot 30 & \end{array}$

\begin{tabular}{|c|c|c|c|}
\hline & & sectio & \\
\hline & (a) & (b) & (c) \\
\hline SE of means in body of table & \pm 0.07 & \pm 0.14 & \pm 0.06 \\
\hline SE of period I treatment means & \pm 0.05 & \pm 0.10 & \pm 0.04 \\
\hline SE of period 2 treatment means & \pm 0.04 & \pm 0.07 & \pm 0.03 \\
\hline
\end{tabular}

Daily food consumption. Animals that had received the $2 \%$ level of vitamin or trace-mineral supplement in the diet during period I ate $6 \%(P<0.0 \mathrm{I})$ more food daily while they were increasing from 25 to $50 \mathrm{lb}$ live weight than their corresponding litter-mates. In period 2 animals given the low-starch diet ate $12 \%$ more food daily $(P<0.001)$ than animals given the high-starch diet.

These two effects were additive. Pigs on the low-starch diet that had previously received the $2 \%$ levels of both the vitamin and trace-mineral supplements ate $24 \%$ more food daily than those pigs on the high-starch diet that had previously received the $1 \%$ levels of vitamin and trace-mineral supplements.

Food-conversion efficiency. There was a significant first-order interaction in that pigs on the high-starch diet ate less food per lb of live-weight gain than those on the low-starch diet, but only when they had received the $2 \%$ level of trace-mineral supplement from 8 to $25 \mathrm{lb}$ live weight $(P<0.05)$.

None of the other effects of treatment on food-conversion efficiency were statistically significant. 


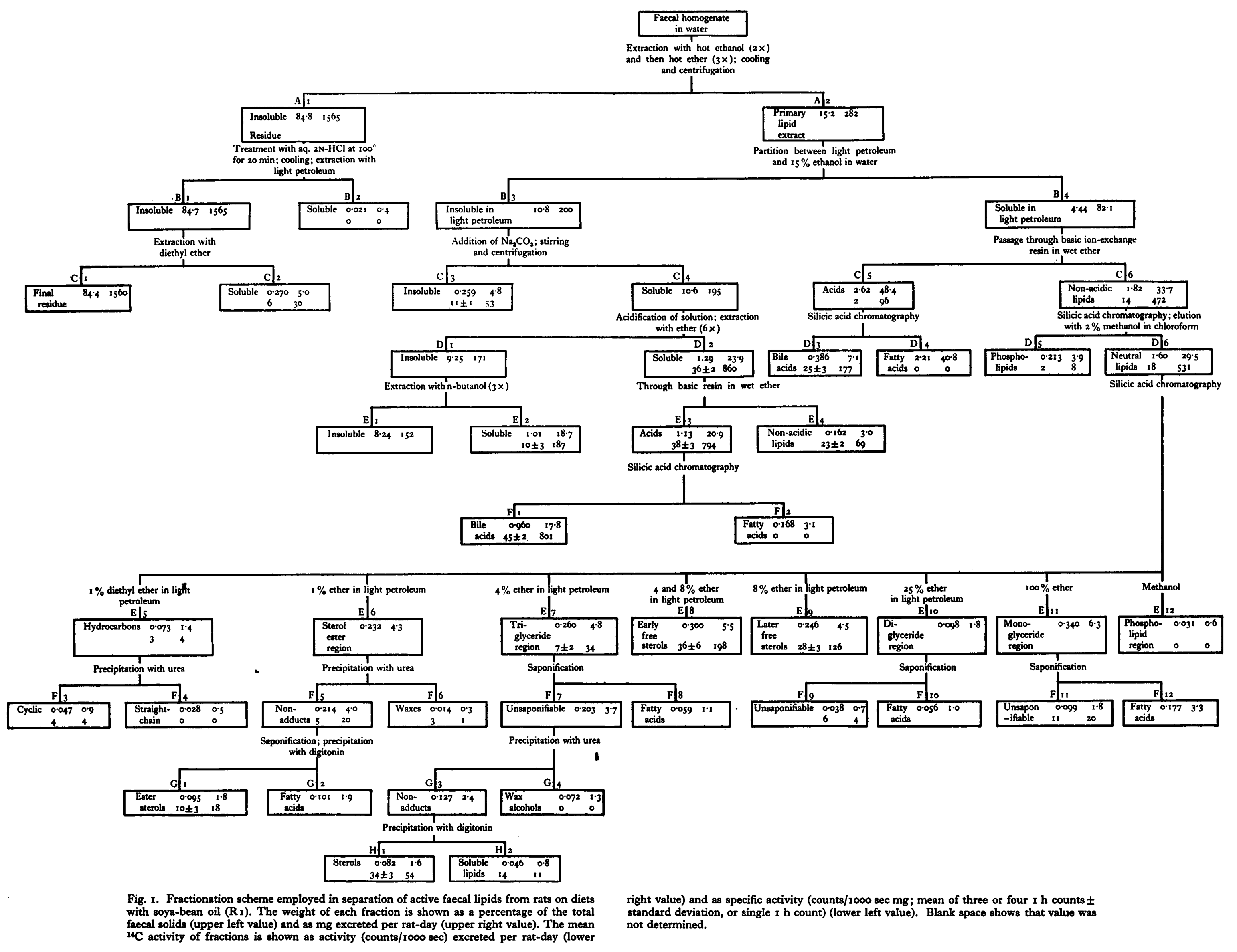


Daily live-weight gain. Pigs that had received the $2 \%$ level of vitamin supplement in the diet during period I grew $9 \%$ faster from 25 to $50 \mathrm{lb}$ live weight than those that had received the I \% level $(P<0.05)$.

None of the other effects of treatment on rate of live-weight gain were statistically significant.

\section{DISCUSSION}

\section{Adequacy of the diets}

Voluntary food intake. The synthetic diets tested were accepted readily by the pigs and mean daily food intakes were as high as intakes of non-synthetic early-weaning diets previously given to pigs of 8-50 lb live weight at this Institute (Smith \& Lucas, 1956-7, 1957; Calder et al. 1959).

In the main experiment daily food consumption was not significantly affected by any of the experimental treatments imposed before the pigs had attained $25 \mathrm{lb}$ live weight, but between 25 and $50 \mathrm{lb}$ live weight the effect of increasing the level of either vitamins or trace minerals was to increase daily food consumption and these effects were additive so that the pigs receiving the higher levels of both vitamins and trace minerals had a higher food intake than those receiving the higher level of either alone. The level of starch in the diets given during the second period had the greatest effect on daily food consumption, which was $12 \%$ higher with pigs given the low-starch than with those given the high-starch diet, possibly because the higher sugar content made it more acceptable.

Utilization and weight gain. Since the diets had a higher gross energy value and were probably more highly digestible than the non-synthetic early-weaning diets used by Smith \& Lucas (1956-7) and by Calder et al. (1959), gain in weight was slightly faster in this experiment than with these other diets.

Neither food-conversion efficiency nor daily weight gain was significantly affected by any of the experimental treatments imposed before the pigs had attained $25 \mathrm{lb}$ live weight, although the preliminary experiments had suggested that food-conversion efficiency and daily weight gain were better when the diet contained $2 \%$ of vitamins and trace minerals. The results of the preliminary experiments cannot be regarded as completely reliable, however, owing to the small number of animals.

During the second period of the main experiment daily weight gain was $9 \%$ higher in those pigs that had previously received the $2 \%$ level of vitamins. Neither daily weight gain nor food-conversion efficiency was affected by level of starch in the diet.

Nutritional adequacy. The diets supported a high rate of weight gain which was considered satisfactory since estimates of requirements for calcium and other nutrients should be made on rapidly growing animals. However, the physical appearance of the pigs at the end of the experiment was not quite normal, the animals being hairy and having rough skins. This effect and the fact that the level of vitamins and trace minerals given before a live weight of $25 \mathrm{lb}$ had been reached affected performance between 25 and $50 \mathrm{lb}$ suggest that one or more of the vitamins or minerals was not present in the diet in sufficient amount or that some other dietary essential was lacking.

At the end of the experiment it was found that many animals showed signs of leg 
weaknesses which the dietary or therapeutic treatments did not correct. It seemed probable that the poor bone development was due to an insufficiency of $\mathrm{Ca}$ and $\mathrm{P}$ in the diets. The contents were $0.87 \% \mathrm{Ca}$ and $0.92 \% \mathrm{P}$ in diet $\mathrm{I}$ and $0.65 \% \mathrm{Ca}$ and $0.67 \% \mathrm{P}$ in diet $\mathrm{I}_{3}$, calculated on an air-dry basis. Subsequent experiments (Blair \& Benzie, 1960, unpublished) have confirmed that diet I did not contain sufficient of these elements to meet the requirements of the $8-25 \mathrm{lb}$ pig.

Of the synthetic diets tested, that judged most suitable for subsequent nutritional investigations in this laboratory on pigs of $8-25 \mathrm{lb}$ live weight was diet I (Table $\mathrm{r}$ ) modified to contain $2 \%$ of the vitamin and $2 \%$ of the trace-mineral supplements and probably $\mathrm{I} \cdot 0-\mathrm{I} \cdot 2 \% \mathrm{Ca}$. A diet similar to the high-starch diet ( 13 , Table $\mathrm{I}$ ), but probably containing $0.8-\mathrm{r} \% \mathrm{Ca}$ would be equally satisfactory and more economical than the low-starch diet for the pigs weighing $25-50 \mathrm{lb}$.

\section{Disease}

Disease, which can cause difficulty in the rearing of pigs, was not a serious problem in this experiment. Scouring was encountered in all the litters but the pigs responded well to treatment. More serious was the $C$. albicans infection which, fortunately, was rapidly diagnosed although it has not previously affected pigs at this Institute. Catron (1957) is quoted by Combs et al. (1958) as having observed an increase in the incidence of $C$. albicans infection in pigs with continuous use of broad-spectrum antibiotics especially when given at high levels, but there are only a few published reports of its occurrence in pigs. Quin (1952) makes a short reference to the disease, associating it with side effects after excessive intakes of antibiotics. Gitter \& Austwick (1959) describe the pathology of the disease in a litter of suckling pigs, and McCrea \& Osborne (1957) give an account of the condition in one pig affected out of a litter receiving a semi-synthetic diet. Recently Osborne, McCrea \& Manners (1960) have published observations on the occurrence of the disease and its treatment with nystatin in 140 young pigs reared artificially on a semi-synthetic diet containing $0.0015 \%$ penicillin. Clinical signs, similar to those already described, were recorded and an extensive description of pathological and histological findings was presented. C. albicans is normally regarded as a commensal which under certain circumstances becomes pathogenic, for example with removal of competitors by antibiotic treatment in man (Blyth, r958), but it does seem to be significant that in three of the five recorded cases (including the pig reported here) the diets used were purified ones. Something other than removal of competitors may, therefore, affect pathogenicity. The disease is common in turkeys and man, and according to Blyth it is on the increase in man. Control is straightforward since the discovery that nystatin is effective in inhibiting the growth of this fungus (Yacowitz et al. 1957). It would appear desirable, therefore, to include this antibiotic in purified diets as a safeguard against fungal infection. 


\section{SUM MARY}

I. Dry, synthetic diets consisting of casein, maize starch, sugars, fats, vitamins, trace minerals and antibiotics were given to young pigs ( $\mathrm{I}$ ) from 8 to $25 \mathrm{lb}$ live weight and (2) from 25 to $50 \mathrm{lb}$ live weight.

2. As a result of a preliminary investigation, the main experiment was carried out in a $2 \times 2 \times 2$ factorial design to test the effects of increasing the level of vitamin and trace-mineral supplements from I to $2 \%$ for pigs weighing $8-25 \mathrm{lb}$ and of giving a diet high in starch or low in starch to pigs weighing $25-50 \mathrm{lb}$.

3. The dietary treatments had no significant effect on daily food consumption, food-conversion efficiency, daily weight gain or incidence of scouring in pigs weighing 8-25 lb.

Between 25 and 50 lb live weight, the effect of a previous increase in the level of either vitamins or trace minerals in the diet was to increase daily food consumption by $6 \%(P<0.01)$, and these effects were additive. The effect of a previous increase in the level of vitamins in the diet was also to increase the rate of daily weight gain by $9 \%(P<0.05)$. Food-conversion efficiency was not significantly affected by previous treatment.

The level of starch in the diet given to the pigs weighing $25-50 \mathrm{lb}$ affected daily food consumption, which was $12 \%(P<0.001)$ higher with those given the low-starch diet, but did not significantly affect food-conversion efficiency or rate of daily weight gain.

4. The diets were accepted readily by the pigs and supported a high rate of weight gain. Suitable synthetic diets, based on those tested but modified in the light of experimental findings, are suggested for nutritional investigations on young pigs.

I thank Professor I. A. M. Lucas for help in planning the work described and in the preparation of this paper; Mr A. W. Boyne for the statistical analysis of the results; Cyanamid of Great Britain Ltd and E. R. Squibb and Sons Ltd for the gift of Aureomycin hydrochloride $98 \%$ and Mycostatin 20, respectively; Mr I. Robb for the photography, and Mr I. Philip for help in the care of the animals.

\section{REFERENCES}

Aldinger, S. M., Homeyer, P. G., Speer, V. C., Hays, V. W. \& Catron, D. V. (1957). F. Anim. Sci. 16, 1040.

Blyth, W. (1958). Mycopathologia, ro, 91.

Calder, A. F. C., Lodge, G. A. \& Blair, R. (1959). F. agric. Sci. 53, 130.

Catron, D. V., Nelson, L. F., Ashton, G. C. \& Maddock, H. M. (1953). F. Anim. Sci. 12, 62.

Combs, G. F., Romoser, G. L. \& Shaffner, C. S. (1958). Poult. Sci. 37, 896.

Follis, R. H., Jr. (1958). Deficiency Disease. Springfield, Ill.: C. C. Thomas.

Freese, H. H. (1958). Arch. Tierernähr. 8, 330.

Gitter, M. \& Austwick, P. K. C. (1959). Vet. Rec. 71, 6.

Johnson, B. C., James, M. F. \& Krider, J. L. (1948). F. Anim. Sci. 7, 486.

Lloyd, L. E. \& Crampton, E. W. (1957). F. Anim. Sci. 16, 377.

Lodge, G. A. \& Lucas, I. A. M. (1959). In Scientific Principles of Feeding Farm Live Stock: Proceedings of a Conference held at Brighton, II-1 3 November 1958, p. 125. London: Farmer and Stockbreeder Publications Ltd.

Lodge, G. A. \& McDonald, I. (1959). Anim. Prod. I, 139.

Lucas, I. A. M., Calder, A. F. C. \& Smith, H. (1959). F. agric. Sci. 53, 125.

Lucas, I. A. M. \& Lodge, G. A. (I961). Tech. Commun. Bur. Anim. Nutr., Aberd., no. 22. 
McCrea, M. R. \& Osborne, A. D. (1957). F. comp. Path. 67, 342.

Miller, E. R., Schmidt, D. A., Ullrey, D. E., Hoefer, J. A. \& Luecke, R. W. (1957). F. Anim. Sci. 16, 1039.

Notzold, R. A., Becker, D. E., Terrill, S. W. \& Jensen, A. H. (1955). F. Anim. Sci. 14, 1068.

Osborne, A. D., McCrea, M. R. \& Manners, M. J. (1960). Vet. Rec. 72, 237.

Peo, E. R., Jr., Hays, V. W., Ashton, G. C., Speer, V. C., Liu, C. H. \& Catron, D. V. (1957). F. Nutr. 62, 465 .

Powick, W. C., Ellis, N. R., Madsen, L. L. \& Dale, C. N. (1947). F. Anim. Sci. 6, 3 Io.

Quin, A. H. (1952). Canad. F. comp. Med. 16, 265.

Smith, H. \& I ucas, I. A. M. (1956-7). J. agric. Sci. 48, 220.

Smith, H. \& Lucas, I. A. M. (1957). F. agric. Sci. 49, 409.

Wiese, A. C., Johnson, B. C., Mitchell, H. H. \& Nevens, W. B. (1947). F. Dairy Sci. 30, 87.

Wiese, A. C., Lehrer, W. P., Jr., Moore, P. R., Pahnish, O. F. \& Hartwell, W. V. (1951). Y. Anim. Sci. ro, 80 .

Wintrobe, M. M. (1939). Amer. F. Physiol. 126, 375.

Yacowitz, H., Wind, S., Jambor, W. P., Semar, R. \& Pagano, J. F. (1957). Poult. Sci. 36, I171.

\section{EXPLANATION OF PLATE}

Pl. 1. Pig at 8 weeks of age fed on synthetic diets from 2 weeks showing transient limb deformities. 
British Fournal of Nutrition, Vol. 17, No. I

Plate I

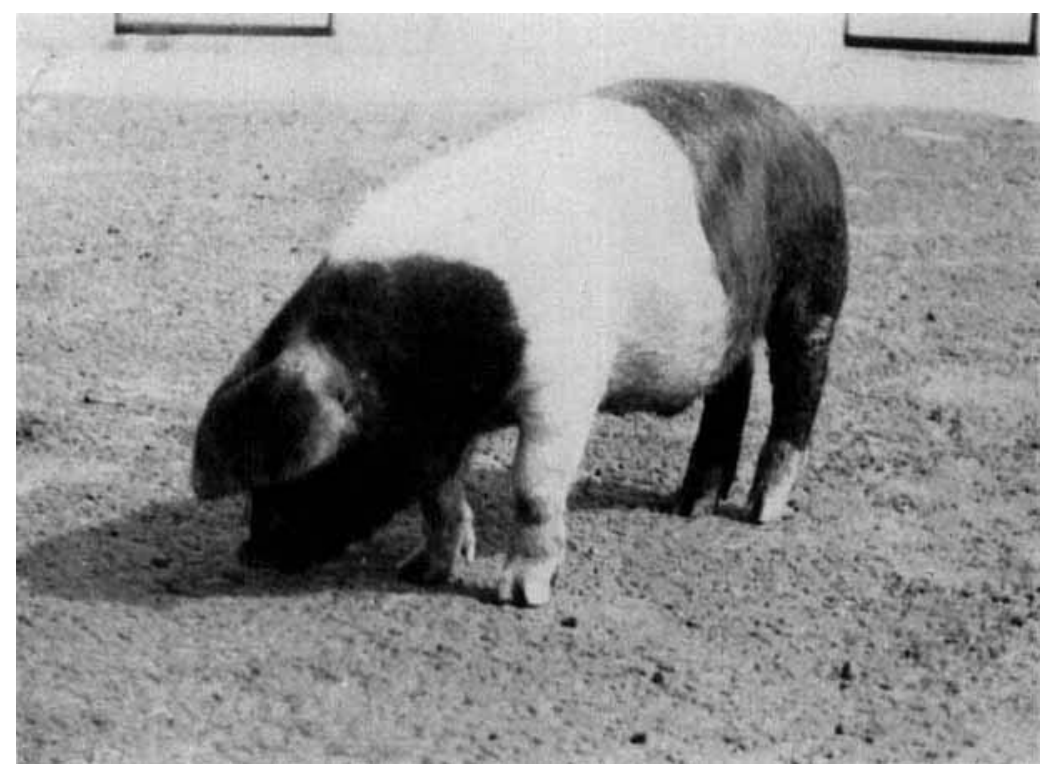

R. BLAIR 